\title{
EFEKTIVITAS MEDIA FILM PENDEK DALAM MENINGKATKAN HASIL BELAJAR PADA PEMBELAJARAN IPS DI KELAS V SEKOLAH DASAR
}

\author{
Dudu Suhandi Saputra ${ }^{1}$, Yuyun Dwi Haryanti ${ }^{2}$ \\ 1,2 Program Studi Pendidikan Guru Sekolah Dasar, FKIP, Universitas Majalengka \\ Email: 1d.suhandi.s@gmail.com ,_2yuyundwiharyanti18@gmail.com
}

\begin{abstract}
This research is motivated by the low learning outcomes of students in social studies learning. This study aims to improve student learning outcomes in social studies learning in class V Cibeber II Elementary School using short film media. The research method used by researchers is classroom action research in collaboration with fifth-grade teachers in Cibeber II Elementary School, with a total of 25 students in class V consisting of 10 male students and 15 female students. This research took place in 3 cycles, each cycle consisting of 3 actions. The techniques used in data collection are observation, tests, interviews, documentation, and field notes. The results showed that the application of short film media could improve student learning outcomes in social studies learning in class V SDN Cibeber II, Ligung District, Majalengka Regency.
\end{abstract}

Keywords: learning outcomes, social science, learning media short movie

\begin{abstract}
Abstrak
Penelitian ini dilatarbelakangi oleh rendahnya hail belajar siswa pada pembelajaran IPS. Penelitian ini bertujuan untuk meningkatkan hasil belajar siswa pada pembelajaran IPS di kelas V Sekolah Dasar Cibeber II dengan menggunakan media film pendek. Metode penelitian yang digunakan oleh peneliti adalah penelitian tindakan kelas yang bekerja sama dengan guru kelas lima di Sekolah Dasar Cibeber II, dengan total 25 siswa di kelas V yang terdiri dari 10 siswa laki-laki dan 15 siswa perempuan. Penelitian ini berlangsung dalam 3 siklus, setiap siklus terdiri dari 3 tindakan. Teknik yang digunakan dalam pengumpulan data adalah observasi, tes, wawancara, dokumentasi, dan catatan lapangan. Hasil penelitian menunjukkan bahwa penerapan media film pendek dapat meningkatkan hasil belajar siswa pada pembelajaran IPS di kelas V SDN Cibeber II Kecamatan Ligung Kabupaten Majalengka. Kata kunci: hasil belajar, ilmu pengetahuan sosial, media pembelajaran film pendek
\end{abstract}

\begin{tabular}{llll}
\hline Received & $: 2020-06-06$ & Approved & $: 2020-07-13$ \\
Reviesed & $: 2020-07-09$ & Published & $: 2020-07-31$ \\
\hline
\end{tabular}

(c) (i) (-) Jurnal Cakrawala Pendas is licensed under a Creative Commons AttributionShareAlike 4.0 International License.

\section{Pendahuluan}

Hasil belajar adalah ukuran atau tingkat keberhasilan yang dapat dicapai oleh seorang siswa berdasarkan pengalaman yang diperoleh setelah dilakukan evaluasi berupa tes dan biasanya diwujudkan dengan nilai atau angkaangka tertentu serta menyebabkan terjadinya perubahan kognitif, afektif, maupun psikomotorik (Dimyati \& Mudjiono, 2009), Nana Sudjana (2010). Lebih lanjut, Lestari (2013), Saputa, Yuliati, Hidayat (2019) mengatakan bahwa Hasil belajar merupakan akibat dari proses belajar seseorang. Hasil belajar terkait dengan perubahan pada diri orang yang belajar. Belajar merupakan suatu proses yang dilakukan secara sadar yang merupakan hasil dari pengalaman manusia itu sendiri. Senada dengan hal tersebut, Aunurrahman (2012), Febriyanto, Sutarna (2020) mengemukakan belajar adalah suatu proses yang dilakukan secara keseluruhan, sebagai hasil pengalaman individu itu sendiri dan dalam interaksi lingkungannya. Lebih lanjut, Hanafy (2014) menyatakan bahwa 
belajar merupakan segala aktivitas baik fisik maupun psikis yang menghasilkan perubahan tingkah laku setiap individu, yang relatif konstan dan tidak bersifat sementara. Artinya bahwa melalui proses yang dinamakan belajar seseorang akan memiliki perubahan tingkah laku namun perubahan tingkah laku ini bersifat tidak sementara. Perubahan tingkah laku tersebut baik dilakukan melalui latihan dan atau pengalaman yang menyangkut aspek kognitif, afektif dan psikomotor.

Ilmu Pengetahuan Sosial merupakan bidang ilmu pengetahuan yang selalu berkenaan dengan kemanusiaan, sehingga dengan pembelajaran Ilmu Pengetahuan Sosial siswa dapat memiliki jiwa sosial yang tinggi dan memiliki sikap tanggung jawab terhadap permasalahan yang terjadi di lingkungannya. Sardjiyo, dkk (2014) yang menyatakan bahwa Ilmu Pengetahuan sosial adalah bidang studi yang mempelajari, menelaah, menganalisis, gejala dan masalah sosial di masyarakat dengan meninjau dari berbagai aspek kehidupan atau satu perpaduan. Dapat dipahami bahwa, Ilmu Pengetahuan Sosial merupakan ilmu pengetahuan yang mempelajari mengenai masyarakat serta masalah sosial yang ada di masyarakat.

Guru sebagai faktor utama dalam keberhasilan pembelajaran IPS harus mampu mengembangkan sistem pembelajaran di kelas secara optimal serta menggunakan model pembelajaran yang inovatif agar mampu menarik perhatian siswa sehingga mengikuti pembelajaran. Salah satu keberhasilan dari pembelajaran IPS adalah tercapainya KKM dari mata pelajaran IPS. Sehingga ditegaskan bahwa permasalahan yang dihadapi dalam pembelajaran IPS ini yaitu lemahnya kualitas pembelajaran. Proses pembelajaran IPS di jenjang persekolahan terutama di sekolah dasar perlu adanya pembaharuan yang serius, berbagai kelemahan dari pembelajaran IPS salah satunya yaitu pembelajaran yang masih dominan berpusat pada guru, hal ini dapat menyebabkan lemahnya proses pembelajaran yang berdampak pada rendahnya hasil belajar siswa pada mata pelajaran IPS. Kegiatan pembelajaran yang seperti ini dapat menimbulkan kebosanan dan ketidak tertarikan siswa dalam mengikuti pembelajaran sehingga pemahaman siswa menjadi kurang.

Berdasarkan hasil studi pendahuluan melalui observasi dan wawancara yang dilakukan di kelas V SDN Cibeber II Kecamatan Ligung Kabupaten Majalengka diperoleh data, yaitu dari keseluruhan siswa sebanyak 25 siswa, hanya 7 orang saja yang mencapai nilai Kriteria Ketuntasan Minimal (KKM) yaitu 70, sedangkan sisanya yang berjumlah 18 orang dibawah KKM. Hal tersebut terjadi karena proses pembelajarannya dominan berpusat pada guru dan siswa hanya menjadi pendengar saja tanpa terlibat aktif dalam proses pembelajaran. Apabila ini dibiarkan berlarut-larut dikhawatirkan akan berdampak pada pencapaian hasil belajar IPS secara keseluruhan. Sehingga hal ini perlu mendapatkan perhatian secara khusus. Upaya yang dapat dilakukan untuk memperbaiki rendahnya hasil belajar siswa pada pembelajaran IPS yaitu dengan cara memperbaiki proses pembelajaran IPS, sehingga siswa bukan hanya sekedar tahu konsep melainkan faham terhadap konsep dan pada akhirnya mampu memanfaatkan pengetahuan IPS yang dimilikinya untuk menyelesaikan berbagai permasalahan yang dialami siswa dalam kehidupan sehari-hari.

Salah satu alternative yang dapat digunakan dalam memperbaiki proses pembelajaran IPS tersebut, dapat dengan menggunakan media film pendek. Peneltiian mengenai media film pendek telah dilakukan oleh Auliyah, Flurentin (2016) tentang efektivitas penggunaan media film untuk meningkatkan empati siswa kelas VII SMP menunjukan bahwa media film efektif untuk meningkatkan empati siswa Kelas VII SMP. Selanjutnya penelitian yang telah dilakukan oleh Ichsan, Rusdi, Sartono (2017) tentang hasil belajar system saraf menggunakan film pendek menunjukan bahwa media pembelajaran film pendek berkategori baik dan efektif digunakan dalam pembelajaran. Lebih lanjut, penelitian yang telah dilakukan oleh Astuti, 
Mustadi (2014) mengenai pengaruh penggunaan media film animasi terhadap keterampilan menulis karangan narasi siswa Kelas V SD menunjukan bahwa terdapat pengaruh penggunaan media film animasi terhadap keterampilan menulis karangan narasi siswa kelas $\mathrm{V}$ SD. Berdasarkan pemaparan di atas, peneliti perlu melakukan kajian secara imliah mengenai efektivitas media film pendek dalam meningkatkan hasil belajar pada pembelajaran IPS di Kelas V Sekolah Dasar.

\section{Metode Penelitian}

Metode penelitian ini menggunakan metode penelitian tindakan kelas dengan mengamati elemen kegiatan, tindakan yang diajukan untuk memperbaiki masalah dalam proses pembelajaran, dan kelas yang sama menerima pelajaran dari seoran guru (M.G.E;2011), (Sugiyono; 2013), Saputra (2017), Saputra at al (2019) Pengumpulan data dilakukan melalui: observasi, wawancara, dokumentasi, dan hasil belajar siswa dari 25 orang. Teknik analisis data dilakukan melalui reduksi data, tabulasi data pengamatan, analisis data, dan paparan data. Kriteria keberhasilan dalam penelitian ini adalah jika skor pemahaman bacaan siswa mencapai setidaknya $75 \%$ atau 18 orang dari kriteria ketuntasan minimum. Penelitian ini dilakukan melalui empat fase siklus termasuk: perencanaan, pelaksanaan tindakan, pengamatan dan refleksi. Model penelitian tindakan kelas yang digunakan adalah model John Elliot.

\section{Hasil dan Pembahasan}

Penelitian ini menggunakan pendekatan penelitian tindakan kelas dimana penelitian akan membahas hasil dari setiap siklus tindakan yang diberikan. Diagram berikut menunjukkan hasil penelitian ini:

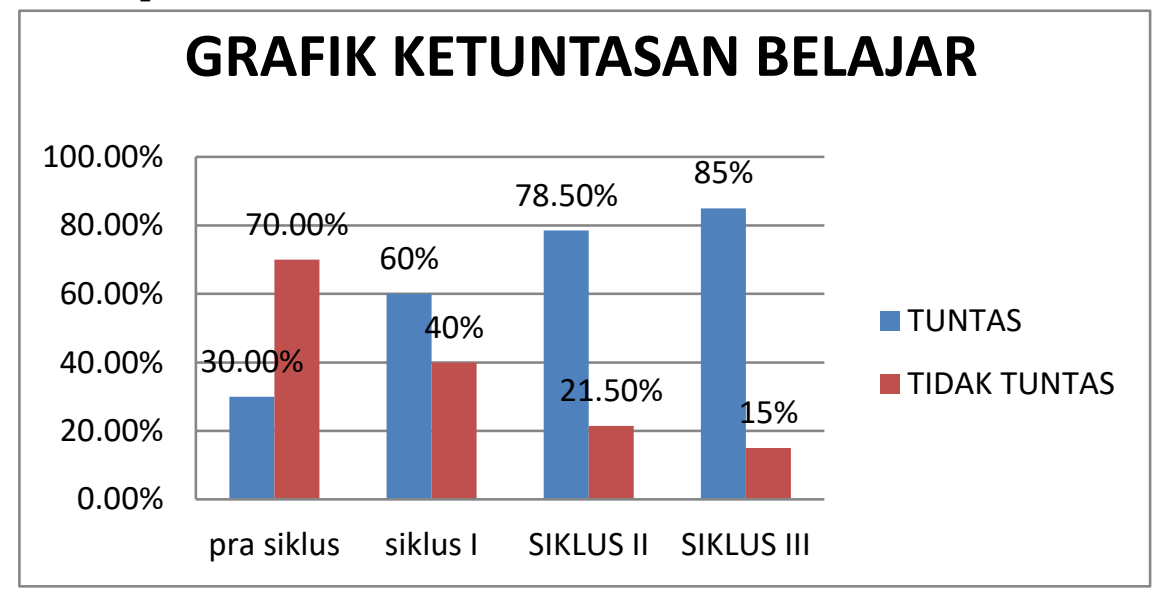

\section{Gambar 1. Grafik ketuntasan belajar pada setiap siklus}

Berdasarkan gambar di atas dipahami bahwa terdapat peningkatan pada setiap siklusnya. Sebelum pelaksanaan tindakan (pra siklus) siswa yang tuntas sebanyak $30 \%$ dan yang belum tuntas sebanyak $70 \%$ dengan nilai rata-rata 56,00 . Pada siklus I siswa yang tuntas sebanyak $60 \%$ sedangkan yang belum tuntas $40 \%$ dengan nilai rata-rata 66,00 . Siklus II mengalami peningkatan ketuntasan belajar siswa dengan siswa yang tuntas 78,50\% dan yang belum tuntas $21,50 \%$ dengan nilai rata-rata 78,60 . Pada siklus ke III jumlah siswa yang tuntas sebesar $85 \%$ dan yang belum tuntas $15 \%$ dengan nilai rata-rata 88,50 .

Hasil penelitian yang telah dipaparkan di atas menunjukan bahwa terdapat kenaikan nilai rata-rata hasil belajar siswa pada setiap siklusnya. Hal tersebut dapat dilihat dari nilai rata-rata hasil belajar pada pra siklus yaitu 56,00 dengan persentase ketuntasan sebesar 
$30,00 \%$, sedangkan nilai rata-rata hasil belajar siswa pada siklus I yaitu 66,00 dengan persentase ketuntasan sebesar $60 \%$. Dapat dipahami bahwa, peningkatan nilai rata-rata hasil belajar siswa pada pembelajaran IPS dari pra siklus ke siklus I sebesar 10,00 dengan peningkatan presentase ketuntasan dari pra siklus ke siklus I sebesar 30\%. Selanjutnya, nilai rata-rata dari siklus I ke siklus II pun mengalami peningkatan yang signifikan. Hal tersebut dapat dilihat dari nilai rata-rata pada siklus II yaitu 78,60 dengan ketuntasan belajar 78,50\%. Dapat dipahami bahwa, nilai rata-rata siklus I ke siklus II terdapat kenaikan sebesar 12,6 dengan kenaikan persentase ketuntasan belajar sebesar 18,5\%. Berikutnya, nilai rata-rata pada siklus II ke siklus III juga mengalami kenaikan yang sangat signifikan. Hal ini dapat dilihat dari kenaikan nilai rata-rata siklus II ke siklus III sebesar 9,9 dengan kenaikan persentase ketuntasan belajar sebesar 6,50\%. secara umum dpaat disimpulkan, bahwa dalam meningkatkan hasil belajar siswa pada pembelajaran IPS di Kelas V Sekolah dasar dapat dengan menggunakan media film pendek.

Hasil penelitian di atas sejalan dengan hasil penelitian yang telah dilkuakan oleh Rahmatullah (2011) yang menunjukan bahwa hasil belajar siswa yang belajar dengan menggunakan media film pendek lebih tinggi dibandingkan siswa yang belajar dengan tidak menggunakan media film pendek. Lebih lanjut, penelitian yang telah dilakukan oleh Muharria, Yusuf, Kartika (2016) menunjukanbahwa media film pendek efektif dalam meningkatkan hasil belajar siswapada pembelajaran sejarah di Sekolah Menengah Atas.

Baksin (2014) mengatakan bahwa Film adalah media komunikasi massa yang berfungsi untuk menyampaikan pesan atau materi komunikasi. Lebih lanjut, Mabruri (2014) mengatakan bahwa Film pendek merupakan film yang durasinya pendek yaitu dibawah 60 menit dan didukung oleh cerita yang pendek. Dengan demikian, Film pendek ini memungkinkan guru untuk mengolah dan mengemas film secara singkat namun bermakna.

\section{Kesimpulan}

Berdasarkan hasil penelitian yang telah dijelaskan, dapat disimpulkan bahwa media film pendek dapat meningkatkan hasil belajar siswa pada pembelajaran IPS di kelas V Sekolah Dasar. Peningkatan nilai hasil belajar dipengaruhi oleh aktivitas siswa dan guru dalam proses pembelajaran di kelas. Media film pendek memiliki dampak positif pada siswa terhadap antusiasme untuk belajar IPS karena merumuskan teknik pembelajaran sangat menyenangkan sehingga siswa tidak merasa bosan saat mempelajari materi.

\section{Daftar Pustaka}

Anurrahman. (2013). Belajar dan Pembelajaran. Bandung: Alfabeta.

Astuti, Y.W., Mustadi, y. (2014). Pengaruh penggunaan media film animasi terhadap keterampilan menulis karangan narasi siswa kelas V SD. Jurnal Prima edukasia, Vol 2 No 2.

Auliyah, A., Flurentin, E. (2016). Efektivitas penggunaan media film untuk meningkatkan empati Siswa Kelas VII SMP. Jurnal kajian bimbingan dan konseling, Vol 1, No. 1.

Baksin, A. (2014). Jurnalistik Televisi : Teori dan Praktik. Bandung :PT Remaja Rosdakarya.

Dimyati dan Mudjiono. (2009). Belajar dan pembelajaran. Jakarta: Rineka Cipta

Febriyanto, B., Sutarna, N. (2020). Effectivity photo story media usage in direct reading thinking activity methods towards ability understanding stories skills of elementary school students. Journal of physics: conference series, Vol 1477.

Hanafy, S,M. (2014). Konsep Belajar dan Pembelajaran.jurnal Lentera Pendidikan. Vol 17, No. 7.

Ichsan, I.Z., Rusdi, Sartono, N. (2017). Hasil belajar system saraf menggunakan film pendek. Biosfer: jurnal pendidikan biologi, Vol. 10, No. 2.

Lestari, I. (2013). Pengaruh waktu belajar danminat belajar terhadap hasil belajar matematika. Formatif: jurnal ilmiah pendidikan MIPA, Vol. 3, No. 2. 
142 Saputra, Haryanti, Efektivitas media film...

M. G. E, (2011). Action research, A guide for the teacher researcher 2nd. New Jersey: Merrill Prentice Hall.

Mabruri, A. (2014). Manajemen Produksi Program Acara Televisi. Depo: Mind 8 Publishing House.

Muharria, Yusuf, S., Kartika, S. (2016). Pengaruh penerapan media film pendek sebagai sumber pembelajaran sejarah terhadap hasil belajar siswa di kelas $X$ matematika ilmu alam sekolah menengah atas Negeri 13 Palembang. Criksetra: Jurnal pendidikan sejarah, vol 5, No. 1

Nana Sudjana. (2010). Penilaian hasil proses belajar mengajar. Bandung: PT. Remaja Rosdakarya.

Rahmatulla, M. (2011). Pengaruh pemanfaatan media pembelajaran film animasi terhadap hasli belajar. Jurnal penelitian pendidikan VO1.1, No. 1.

Saputra, At A1. (2019). Use ladder snack media inn improving student learning outcomes in mathematics learning in elementary school. Journal of physics: conference series, Ser. 1363 012058

Saputra, D.S. (2017). Interactive learning dalam pembelajaran speaking di kelas V Sekolah Dasar. Jurnal cakrawala PENDAS, Vol 3 No. 1.

Saputra, D.S., Yuliati, Y., Hidayat, D.A. (2019). Penerapan pendekatan realistic mathematic education dalam meningkatkan hasil belajarasiswa. Numeracy: Jurnal ilmiah pendidikan matematika, Vol. 6, No.2.

Sardjiyo. (2014). Pendidikan IPS di SD. Tangerang Selatan: Universitas Terbuka.

Sugiyono. (2013). Model Penelitian Kombinasi (Mix Methods).Bandung: Alfabeta. 